Fountain Journal of Natural and Applied Sciences 2017; 6(1): 34-41
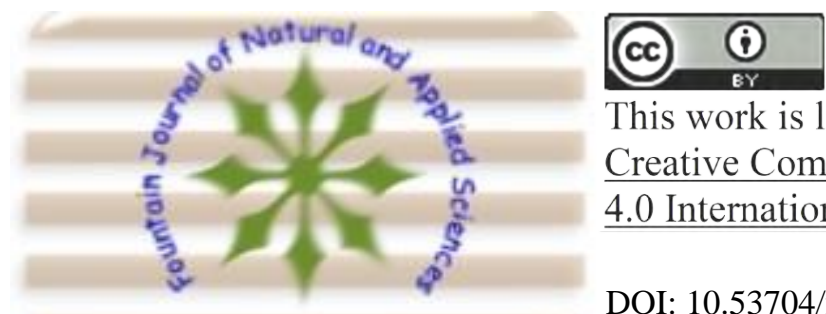

This work is licensed under

Creative Commons Attribution

4.0 International License.

DOI: 10.53704/fujnas.v6i1.160

A publication of College of Natural and Applied Sciences, Fountain University, Osogbo, Nigeria.

Journal homepage: www. fountainjournals.com

ISSN:2354-337X(Online),2350-1863(Print)

\title{
Game-Based Learning for Effective Teaching of Computer Studies in Secondary Schools
}

\author{
${ }^{1}$ Shittu, A.J.K, ${ }^{2}$ Adedokun-Shittu, N.A. and ${ }^{2}$ Abdulsalam, R.O. \\ ${ }^{1}$ Department of Mathematical and Computer Sciences, Fountain University Osogbo, Osogbo, Osun Nigeria. \\ ${ }^{2}$ Department of Educational Technology. Faculty of Education. University of Ilorin, Nigeria.
}

\begin{abstract}
Game-based learning among Nigerian secondary schools is not common. In foreign countries where gamebased learning is widely used, it is often believed that it could be more distracting and may not align with learning goals. Considering this stance, it is imperative to investigate among teachers and students if this approach would be effective for teaching computer studies before it could be recommended for implementation. Thus, the need for this study which investigated students and teachers' perception on gamebased learning for effective teaching of computer studies in secondary schools, Ilorin. Specifically, the study investigated secondary school teachers and students' awareness of game-based learning, their attitude to game-based learning and their readiness toward game-based learning for effective teaching. It also examined the respondents' perception toward the usefulness of game-based learning for effective teaching. The researcher demonstrated the use of game-based learning with the teaching of Network Routing by playing the orange game as found on CS unplugged. This is to ensure that both teachers and students understand the concept of game-based learning before attempting the survey. This study adopted a descriptive research using a survey method. A purposive sampling of one hundred and twenty-five (125) students and twenty-five (25) teachers were used on the target population of schools in Ilorin South local government, Kwara state, Nigeria. Percentage (\%) statistical method and standard deviation were used to analyze the data obtained. The findings implied that teachers should be encouraged to use student-centered approach in their teaching for effective learning. It was recommended among others that secondary school teachers should make use of game-based learning since they are all aware and ready to use it for their teaching of computer studies.
\end{abstract}

Keywords: Game-based learning, Educational games, Computer games, Computer studies

\section{Introduction}

Game is a set of activities involving one or more players with a set goal, constraints and consequences. A game is rule-guided and involves some aspects of a contest or a trial of skill or ability (Kasvi, 2000). Games and gaming activities have been in existence from the time immemorial and gradually becoming an integral part of modern society. The fact that games are immersive and engaging in a way that traditional workbooks or manuals are not,

*Corresponding author: +2347011104431

Email address: abdjaleel@fuo.edu.ng 
constitutes the primary source of appeal to education and training professionals because students are highly motivated and are more likely to engage in devote effort to persist longer at a particular activity. Asaolu (2011) submitted that there is need to adopt educational games and incorporate such into the curriculum at all levels. The academic research community has begun to pay significant attention to the ways in which games might support learning which is one of the motive of conducting this study. The academic research community has begun to pay significant attention to the ways in which games might support learning either in a distributed environment or not (Shittu \& Hassan, 2008).

The use of games as a teaching aid in Nigeria educational system is still at its early stages. Limited number of scholarly articles (Asaolu, 2011; Babayemi \& Akinsola, 2009); mentioned educators view about the use of games in Nigeria. It would therefore be unwise to suggest integrating games in the classroom without knowing the teachers and students' awareness, attitude and readiness towards it. This study attempts to fill this gap in the literature.

However, in advanced countries several studies have been carried out on the effectiveness of gamebased learning in education. Though, much of the early research on game-based learning focused on negative impacts. Ebru and Muhammet, (2013) researched on secondary and high school teachers' perception regarding computer games with educational features and revealed that teachers' perceptions about game-based were negative, because "playing computer games affect the social life of the people negatively" and using game-based method is a waste of time. Contrarily, many more studies have been conducted on teachers and students' awareness along their attitude, and readiness on game-based that revealed positive results. A number of studies have suggested that the majority of K-12 school teachers adopt a positive attitude towards the use of game-based in education. Most teachers think that game-based method could motivate students to learn and playing games can support the development of a variety of skills (Can \& Cagiltay, 2006; Koh et al., 2011; Sandford, Ulicsak, Facer, \& Rudd, 2006; Wastiau, Kearney, \& den Berghe, 2009).

Wastiau et al. (2009) investigated over 500 teachers' in several European countries about their opinions of using games for instruction, and found that most of the teachers' have used games in their teaching and they wanted to know more about how to use games as teaching tools. They believed that students are motivated and can obtain certain skills such as social and spatio-temporal skills with educational games. Similarly, Johnson (2005) asserted that playing games gives learners a "mental workout", he further claimed that players of educational games are faced with a stream of decisions, and must engage with problem solving strategies. Similarly, Garris, Ahlers, and Driskell (2002) indicate that educational games engage students in repeated judgment-behavior-feedback loops.

In the same vein, (McFarlane, Sparrowhawk, and Heald, 2002) established a correlation between game-playing and the potential to develop skills in decision making, design, strategy, cooperation, and problem solving. On top of that, certain practices of educational games (e.g., Narration, Reward, and Game Mechanics) have proved their value on the learning arena (Cohen Group Report, 2011; Isaacs, 2015). Good game-based learning applications can draw students into virtual environments that look and feel familiar and relevant. This keeps them highly engaged in practicing behaviors and thought processes that can be easily transferred from the simulated environment to real life situation.

Although, game-based learning requires teachers to keep up to date with the content of the game in every aspect and should be able to determine whether the content of the game is appropriate for specific age group, this without jeopardizing the suitability and relevance to education standard. There should be an interaction between the students and the game, and possibly among their peers, which will make it interesting, fun and easier for students to figure out the exact information needed to be passed across from the topic. 


\section{Methodology}

This research used a quantitative survey with two sets of self-designed instruments to elicit responses from teachers and the students on their perception, awareness, attitude and readiness to use game-based learning for instruction. The questionnaire was in three parts $A, B$ and $C$. Section $A$ caters for the demographic information of the respondents for both teachers and students, section B consists of the awareness, attitude, and readiness of game-based learning for both the teachers and the students, while section $C$ compose of the perception of teachers and students on the usefulness of the game-based learning. Purposive sampling techniques was used to select five sample schools and 150 respondents consisting one hundred and twenty-five (125) students and twenty-five (25) teachers. Most secondary schools in Kwara state take computer studies as a subject because it is included in their curriculum but few of them make use of game-based learning. Among this few are five (5) secondary schools in Ilorin South Local Government Area purposively selected for this study. The samples were drawn from teachers teaching computer studies and students from the upper basic class since the topic chosen for the game-based learning (Network Routing) is for upper basic curriculum. Descriptive statistics of frequency counts and Percentage were used to analyze the demographic information of the respondents while mean and standard deviation were used to answer the research questions raised - "how do teacher and students perceive the usefulness of game-based learning for effective teaching of computer studies?" and "what are teacher and students' awareness, attitude and readiness towards the use of game-based learning for effective teaching of computer studies?". - needs empirical data for this.

\section{Results}

The results were analysed based on the scales represented in the questionnaire: teachers and students' awareness, attitude, readiness and perceived usefulness of game-based learning. The analysis are presented sequentially in the tables below. Table 1 shows that 23 (92\%) of the respondents are aware of game based learning while $2(8 \%)$ are not. $17(68 \%)$ of the respondents have attended seminars or read game based learning while $8(32 \%)$ have not. $16(64 \%)$ of the respondents are aware that the orange game can be used to teach routing in networking while $9(36 \%)$ are not.

Table 1: Analysis of teachers' awareness of game-based learning for effective teaching

\begin{tabular}{|c|c|c|c|c|}
\hline Items & Yes & No & Mean & $\begin{array}{l}\text { Standard } \\
\text { deviation }\end{array}$ \\
\hline $\begin{array}{l}\text { Are you aware of } \\
\text { game based } \\
\text { learning? }\end{array}$ & 23 & 2 & 1.08 & 0.277 \\
\hline $\begin{array}{l}\text { Have you } \\
\text { attended } \\
\text { seminars or read } \\
\text { about game } \\
\text { based learning? }\end{array}$ & 17 & 8 & 1.32 & 0.476 \\
\hline $\begin{array}{l}\text { Are you aware } \\
\text { that the orange } \\
\text { game can be used } \\
\text { to teach routing } \\
\text { in networking } \\
\text { easily? }\end{array}$ & 16 & 9 & 1.36 & 0.490 \\
\hline
\end{tabular}

Table 2: Analysis of teachers' attitude toward game-based learning for effective teaching

\begin{tabular}{|c|c|c|c|c|}
\hline Items & Yes & No & Mean & $\begin{array}{l}\text { Standard } \\
\text { deviation }\end{array}$ \\
\hline $\begin{array}{l}\text { Have you used } \\
\text { this orange } \\
\text { game to teach in } \\
\text { class before? }\end{array}$ & 6 & 19 & 1.76 & 0.436 \\
\hline $\begin{array}{l}\text { Does orange } \\
\text { game learning } \\
\text { improve } \\
\text { teaching? }\end{array}$ & 20 & 5 & 1.20 & 0.408 \\
\hline $\begin{array}{l}\text { If orange game } \\
\text { is complex will }\end{array}$ & 20 & 5 & 1.80 & 0.408 \\
\hline $\begin{array}{l}\text { you prefer } \\
\text { traditional }\end{array}$ & & & & \\
\hline $\begin{array}{l}\text { method of } \\
\text { teaching }\end{array}$ & & & & \\
\hline
\end{tabular}

Table 2 shows the attitude of teachers towards game based learning. It reveals that $6(24 \%)$ have 
Fountain Journal of Natural and Applied Sciences 2017; 6(1): 34-41

used orange game to teach in class before while $19(76 \%)$ have not. $20(80 \%)$ testified that orange game learning has improve their teaching while $5(20 \%)$ does not. Lastly, 20(80\%) prefer traditional method of teaching to orange because of its complexity while $5(20 \%)$ do not.

Table 3 indicates that 21 (84\%) can utilize orange game in their teaching while 4 (16\%) cannot, 23 (92\%) can integrate games to teaching while $2(8 \%)$ cannot, lastly $25(100 \%)$ needs extensive training in other to utilize game in teaching.

All the items in table 4 on teachers' perception of the usefulness of game-based learning are above the average mean score of 3.5 except items $3,5,6,9$, $11,12,13$ and 14 with mean scores of $1.68,3.48,3.36$, $3.16,2.92,3.30$ and 3.24 respectively.
Table 3: Analysis on readiness to use game-based learning for effective teaching

\begin{tabular}{lllll}
\hline Items & Yes & No & Mean & $\begin{array}{l}\text { Standard } \\
\text { deviation }\end{array}$ \\
\hline $\begin{array}{l}\text { Can you utilize } 21 \\
\text { orange game in your }\end{array}$ & 4 & 1.16 & 0.374 \\
teaching? & & & \\
$\begin{array}{l}\text { Can you integrate 23 } \\
\text { games to your }\end{array}$ & 2 & 1.08 & 0.277 \\
teaching? & & & \\
Will you need 25 & 0 & 1.04 & 0.200 \\
extensive training & & & \\
in other to utilize & & & \\
games to your & & & \\
teaching?
\end{tabular}

Table 4: Analysis on teachers' perception towards the usefulness of game-based learning for teaching routing and deadlock in networking

\begin{tabular}{|c|c|c|c|c|c|c|}
\hline Items & SA & $A$ & $D$ & SD & Mean & $\begin{array}{l}\text { Standard } \\
\text { deviation }\end{array}$ \\
\hline $\begin{array}{l}\text { Game based learning should be incorporated to primary and } \\
\text { secondary school teaching system }\end{array}$ & 19 & 5 & 1 & 0 & 3.72 & 0.542 \\
\hline Students motivation is enhanced through the game-based learning & 19 & 5 & 0 & 1 & 3.68 & 0.690 \\
\hline Game based learning is a waste of time & 4 & 0 & 5 & 16 & 1.68 & 1.107 \\
\hline Game based learning makes teaching interactive and pleasurable & 16 & 8 & 0 & 1 & 3.56 & 0.712 \\
\hline $\begin{array}{l}\text { it enhances students participation, enthusiastic, focused and } \\
\text { engagement }\end{array}$ & 14 & 9 & 2 & 0 & 3.48 & 0.653 \\
\hline $\begin{array}{l}\text { students who play the game will be able to answer question more } \\
\text { accurately than those who did not play the game }\end{array}$ & 11 & 12 & 2 & 0 & 3.36 & 0.638 \\
\hline students feedbacks are more effective after playing the game & 15 & 8 & 2 & 0 & 3.52 & 0.653 \\
\hline $\begin{array}{l}\text { at the end of the game, students should be able to respond well on } \\
\text { the subject matter }\end{array}$ & 15 & 9 & 1 & 0 & 3.56 & 0.583 \\
\hline games will make teaching easier & 9 & 13 & 3 & 0 & 3.24 & 0.663 \\
\hline $\begin{array}{l}\text { playing the game can be more effective in teaching when used as } \\
\text { teaching aid for the topic }\end{array}$ & 14 & 10 & 1 & 0 & 3.52 & 0.586 \\
\hline playing the game is suitable for every age group & 10 & 9 & 6 & 0 & 3.16 & 0.800 \\
\hline problems arise when teaching with the use of the game & 8 & 7 & 10 & 0 & 2.92 & 0.862 \\
\hline $\begin{array}{l}\text { it help student fulfill cognitive objective of teaching which are } \\
\text { defined in the lesson plan }\end{array}$ & 9 & 12 & 4 & 0 & 3.30 & 0.707 \\
\hline $\begin{array}{l}\text { it goes along with the school's curriculum plans in term of } \\
\text { classroom management }\end{array}$ & 9 & 13 & 3 & 0 & 3.24 & 0.663 \\
\hline $\begin{array}{l}\text { student gain psychomotor and cognitive objective of teaching } \\
\text { which are defined in the lesson plans }\end{array}$ & 14 & 11 & 0 & 0 & 3.56 & 0.507 \\
\hline
\end{tabular}


The contents of the items with low mean scores are: "game-based learning is a waste of time", "it enhances students' participation, enthusiasm and engagement", "students who play the game will be able to answer questions more accurately than those who did not play the game", "games will make teaching easier", "playing the game is suitable for every age group", "problems arise when teaching with the use of the game", "it help student fulfill cognitive objective of teaching which are defined in the lesson plan", "it goes along with the school's curriculum plans in term of classroom management" respectively. Most of these items indicate some issues which must be considered when planning to infuse games into teaching such as: consuming more time than provided in the class timetable, designing the lesson plan to accommodate game rules, making consideration for games in the curriculum and a host of other considerations for successful implantation of games in teaching and learning.

Table 5: Analysis of students' awareness of game-based learning for effective teaching

\begin{tabular}{llllll}
\hline Items & Yes & No & Mean & $\begin{array}{l}\text { Standard } \\
\text { deviation }\end{array}$ \\
\hline $\begin{array}{l}\text { I aware of game } \\
\text { based learning }\end{array}$ & 51 & 1.41 & 0.493 \\
I am aware that 66 & 59 & 1.47 & 0.501 \\
the orange game & & & & \\
can be used for \\
learning routing \\
and deadlock in \\
networking easily \\
I know how to play 95 & 30 & 1.24 & 0.428 \\
the game
\end{tabular}

Table 5 above indicate the awareness of students using game based for learning. Item 1 show that students are aware of game based learning with mean score of 1.41, item 2 also show that I am aware that the orange game can be used for learning routing and deadlock in networking easily with mean score of 1.47 and the last item which sort to know how to play game with mean score of 1.24 respectively.

Table 6 shows the attitude of students towards game-based learning for effective teaching. Item 1
Table 6: Analysis of students' attitude toward game-based learning for effective teaching

\begin{tabular}{lllll}
\hline Items & Yes & No & Mean & $\begin{array}{l}\text { Standard } \\
\text { deviation }\end{array}$ \\
\hline $\begin{array}{l}\text { I would prefer } 113 \\
\text { the game to }\end{array}$ & 12 & 1.10 & 0.296 \\
traditional \\
method of \\
teaching
\end{tabular}

which sort to know if the students would prefer game to traditional method of teaching has a mean score of 1.10 , item 2 revealed that students assimilate more with the use of game based learning with mean score of 1.04. The last item which shows playing the game will be effective has a mean score of 1.05 , indicating that they all have preference for game-based learning.

Table 7: Analysis of students' readiness to use game-based learning

\begin{tabular}{lllll}
\hline Items & Yes & No & Mean & $\begin{array}{l}\text { Standard } \\
\text { deviation }\end{array}$ \\
\hline $\begin{array}{l}\text { I am willing to } \\
\text { engage myself in } \\
\text { the game }\end{array}$ & 2 & 1.02 & 0.126 \\
activities & & & & \\
I am willing to use 123 & 2 & 1.02 & 0.126 \\
the game for \\
learning activities
\end{tabular}

Table 7 above show the readiness of students to use game-based learning. Item 1 which sort to know if the students are willing to engage themselves in the game activities has a mean score of 1.02, the next item which sort to know if the respondents are willing to use the game for learning also has a mean score of 1.02 and the last item with a mean score of 
Table 8: Analysis of students' perception towards the usefulness of game-based learning

\begin{tabular}{|c|c|c|c|c|c|c|}
\hline Items & SA & $A$ & $D$ & SD & Mean & $\begin{array}{l}\text { Standard } \\
\text { deviation }\end{array}$ \\
\hline $\begin{array}{l}\text { I find the orange game effective in learning } \\
\text { routing and deadlock in networking }\end{array}$ & 73 & 47 & 3 & 2 & 3.53 & 0.630 \\
\hline $\begin{array}{l}\text { I understand and assimilate easily during the } \\
\text { game activities }\end{array}$ & 84 & 34 & 1 & 6 & 3.57 & 0.744 \\
\hline $\begin{array}{l}\text { It improve my performance in the subject } \\
\text { matter }\end{array}$ & 91 & 29 & 2 & 3 & 3.66 & 0.634 \\
\hline It facilitates my cognitive ability & 70 & 53 & 1 & 1 & 3.54 & 0.536 \\
\hline $\begin{array}{l}\text { My responses after playing the games are } \\
\text { always positive }\end{array}$ & 60 & 61 & 1 & 3 & 3.42 & 0.638 \\
\hline The game motivates me to play more & 90 & 25 & 6 & 4 & 3.60 & 0.731 \\
\hline The game has too much rules & 19 & 19 & 43 & 44 & 2.10 & 1.06 \\
\hline $\begin{array}{l}\text { I find the challenge activities of the game } \\
\text { interesting }\end{array}$ & 57 & 42 & 11 & 15 & 3.12 & 1.008 \\
\hline $\begin{array}{l}\text { The game is not straight forward as traditional } \\
\text { teaching }\end{array}$ & 37 & 30 & 37 & 21 & 2.66 & 1.078 \\
\hline I prefer game-based to traditional teaching & 60 & 42 & 11 & 12 & 3.20 & 0.959 \\
\hline
\end{tabular}

1.02 and the last item with a mean score of 1.02 respectively shows if the respondents are ready to accept the rules of the game, all of which represent students' readiness to use game for learning.

All the items in table 8 on students' perception of the usefulness of game-based learning are above the average mean score of 3.0 except items 7 and 9, with mean scores of 2.10 and 2.66 respectively. The contents of the items are Item 7 with mean score of 2.10 shows that the game has too much rules, item 9 follow with mean score of 2.66 indicated that the game is not straight forward as traditional teaching. These two items indicate issues that must be considered when integrating games into learning such that the games becomes not too complex for students' comprehension.

\section{Discussions}

The findings revealed that most of the teachers' are aware of game based learning while few of them are not. More than average teachers' have attended seminars or read on game based learning while few of them are not. Not all teachers' are aware that the orange game can be used to teach routing in networking. The findings also reveal that teachers' attitude towards game based learning are low and they have not used the game to teach in class before. Some of them testified that the gamebased learning has improved their teaching but will prefer traditional method of teaching to game because of its complexity and time-consumption. Some teachers' are also willing to incorporate game in their teaching. They agree to utilize orange game in their teaching but submitted that they need extensive training in order to utilize game in teaching.

The attitude of students' towards game-based learning for effective teaching however revealed that students' prefer games to traditional method of teaching. This is in tandem with previous studies showed that the rate of assimilation is faster with the use of game based learning approach. Games have been recognized as being a good tool to promote learners to actively participate in learning activities (Baid \& Lambert, 2010; Kirikkaya, İŞERİ, \&Vurkaya, 2010; Huizenga, Akkerman, Admiraal, \& Dam, 2009). Researchers have indicated that game based learning could be the best way to trigger students' learning motivation (Papastergiou, 2009a; Dickey, 2010; Huang, 2010; Tüzün, Yılmaz-Soylu, 
Karakuş, Inal, \&Kızılkaya, 2009; Tobias, Fletcher, \& Wind, 2014).

\section{Conclusions}

This study concludes that students' perception, attitude and readiness towards game-based learning is better and more encouraging than that of their teachers. The teachers even though willing to integrate game-based learning will require necessary training to learn the nitty-gritty of gamebased learning and its curriculum requirements. The main implication of this study is that teachers should tend towards learner-centered approach so as to improve students' learning.

\section{References}

Adams, D. A., Nelson, R. R., \& Todd, P. A. (1992). Perceived usefulness, ease of use and usage of information technology - A replication. MIS Quarterly, 16(2), 227-247.

Aldrich, C. (2004). Simulations and the future of learning. San Francisco: Pfeiffer Adolescence, 27, 113-122.

Annetta, L. A., Minogue, J., Holmes, S. Y., \& Cheng, M. T. (2009). Investigating the impact of video games on high school students' engagement and learning about genetics Computers \& Education, 53(1), 74-85.

Bajaj, A., \& Nidumolu, S. R. (1998). A feedback model to understand information system usage. Information \& Management, 33(4), 213-224.

Barkatsas, A., \& Hunting, R. (2012). A review of recent research on cognitive, Meta cognitive and affective aspects of problem solving. Nordic Studies in Math Education, 4(4), 1-30

Bekebrede, G.,Warmelink, H. J. G., \& Mayer, I. S. (2011). Reviewing the need for gaming education to accommodate the net generation. Computers \& Education, 57(2), 1521- 1529.

Betz, J. A. (1995). Computer games: Increases learning in an interactive Multidisciplinary environment. Journal of Educational Technology Systems, 24, 195-205.

Bonanno, P., \&Kommers, P. A. M. (2008). Exploring the influence of gender and gaming competence on attitudes towards using instructional games.
British Journal of Educational Technology, 39(1), 97-109

Boyle, E., \& Connolly, T. (2008). Games for learning: Does gender make a difference? In European conference on games based learning, pp. 69-76.

Buckingham, D., \& Burn, A. (2007). Game literacy in theory and practice. Journal of Educational Multimedia and Hypermedia, 16(3), 323-349.

Chou, C., \& Tsai, M. J. (2007). Gender differences in Taiwan high school students' Computer game playing. Computers in Human Behavior, 23(1), 812-824.

Connolly, T. M., Boyle, E. A., MacArthur, E., Hainey, T., \& Boyle, J. M. (2012). A Systematic literature review of the empirical evidence on computer games and Serious games. Computers and Education, 59, 661-686

Computer Science Unplugged 2005 (www.unplugged.canterbury.ac.nz) accessed $20^{\text {th }}$ July, 2017.

Davis, F. D. (1989). Perceived usefulness, perceived ease of use, and user acceptance of Information technology. MIS Quarterly, 13(3), 319-340.

Dawes, L., \& Dumbleton, T. (2002). Computer games in education project. UK:

Dempsey, J. V., Haynes, L. L., Lucassen, B. A., \& Casey, M. S. (2012). Forty simple Computer games and what they could mean to educators. Simulation \& Gaming, 33(2), 157-168.

Durkin, K., \& Barber, B. (2002). Not so doomed: Computer game play and positive adolescent Development. Journal of Applied Developmental Psychology, 23(4), 373-392.

Ebru Yilmaz Ince and Muhammet Demirbilek (2013) Secondary and High School Teachers' Perceptions Regarding Computer Games with Educational Features in Turkey. Anthropologist, 16(1-2): 89-96 (2013)

Smith, L., \& Mann, S. (2002). Educational Technology, Research, and Development, 44(1). Playing the game: $A$ model for gameness in interactive game based learning. In Proceeding of the 15th Annual NACCQ, 397-402. Hamilton, New Zealand.

Egenfeldt-Nielsen, S. (2015). Beyond edutainment: Exploring the educational potential of computer 
Fountain Journal of Natural and Applied Sciences 2017; 6(1): 34-41

games. Ph.D. dissertation, IT University of Copenhagen.

Fengfeng, K. (2008). A case study of computer gaming for math: Engaged learning from gameplay? Computers \& Education, 1609, 1620.

Garris, R., Ahlers, R., \&Driskell, J. E. (2002). Games, motivation and learning. Simulation and gaming. An Interdisciplinary Journal of Theory, Practice and Research, 33(4),43-56.

Gee, J. P. (2013). What video games have to teach us about learning and literacy. New York: Palgrave Macmillan.

Giannakos Michail N. (2013) Enjoy and learn with educational games: Examining factors affecting learning performance

Hartmann, T., \&Klimmt, C. (2006). Gender and computer games: Exploring females' Dislikes. Journal of Computer-Mediated Communication, 11(4), 910-931

Inkpen, K., Klawe, M., Lawry, J., Sedighian, K., Leroux, S., Hsu, D., et al (1994). We have never forgetful flowers in our garden: Girls' responses to electronic games. Journal of Computers.in Mathematics and Science Teaching, 13(4), 383403
Isaacs, S. (2015), The Difference between Gamification and Game-Based Learning. Accessed $20 \quad$ March, 2018 http://inservice.ascd.org/.

Michail N. Giannakos, Konstantions Choranopoulos, Letizia Jaccheri and Nikos Chrisochoides (2015) This Game is Girly!" Perceived Enjoyment and Student Acceptance of Edutainment In Stefan Gobel, Wolfgang Mueller, Bodo Urban and Josef Wemeyer 2015 E-Learning and Games for Training, Education, Health and Sports

Shittu, A. \& Hassan, W.H. (2008). Developing an ELearning Application for a Distributed Environment. In J. Luca \& E. Weippl (Eds.), Proceedings of ED-MEDIA 2008--World Conference on Educational Multimedia, Hypermedia \& Telecommunications (pp. 20242029). Vienna, Austria: Association for the Advancement of Computing in Education (AACE). Retrieved March 23, 2018 from https://www.learntechlib.org/p/28652/

Tobias S., Fletcher J.D., Wind A.P. (2014) GameBased Learning. In: Spector J., Merrill M., Elen J., Bishop M. (eds) Handbook of Research on Educational Communications and Technology. Springer, New York, NY. 